\title{
Legal Obstacles for Chinese Companies Investing in the Infrastructure Construction in the Europea Union: From a Labour Law Perspective
}

\author{
Kai Liu ${ }^{1}$ \\ ${ }^{1}$ Associate Professor in School of Law, Jiangsu Normal University, China \\ Correspondence: Kai Liu, Associate Professor in School of Law, Jiangsu Normal University, China.
}

Received: July 13, 2020

Accepted: July 30, 2020

Available online: August 5, 2020

doi:10.11114/afa.v6i2.4965

URL: https://doi.org/10.11114/afa.v6i2.4965

\begin{abstract}
Annual infrastructure investment by Chinese companies in Europe continues to climb. However, the legal obstacles arising from the labour law system of the European Union has been not paid sufficient attention to. This research has taken use of a legal analyzing approach, to probe into on the one hand, the EU labour law framework; and on the other hand, to analyze the specific aspects of the labour law filed which would lead to the legal obstacles against the Chinese companies investing in the infrastructure construction.
\end{abstract}

Keywords: Chinese infrastructure investment, European Union, the Labour Law, workers' representing bodies, social partners

\section{Introduction}

In the context of the Budapest Guidelines signed by the 6th China-CEE Summit ---- which was held in Riga, Latvia in 2016, and further implemented the 16+1 cooperation framework in an all-round manner ---, China-EU cooperation is increasingly strengthened. Directives passed at the Riga summit 2016 effectively tightened Chinese-CEE cooperation in the areas of relations among civil engineering, financing cooperation and the green economy, the food industry, as well as infrastructure developments. Generally speaking, China is increasingly investing in Europe.(Mitchell et al., 2020; Clegg and Voss,2020). This reflected by the fact that Chinese investors are gearing up for more infrastructure investment in Europe as part of the efforts to expand international trade in response to President Xi Jinping's ambitious Belt and Road initiative.(Casaburi, 2018; McKenzie, 2017).

This research is aimed to examine the labour law system of the European Union (EU) in order to locate out the legal obstacles which exist concerning the investment by the companies from China, and at the same time to put forward possible solutions from the labour law perspective. Generally, the EU, under the Treaty on the Functioning of the European Union, article 153(1) is able to use the ordinary legislation procedure on a list of labour law fields. Meanwhile, it is also noted that labour law and employment law have though slight difference: Labour law generally applies to work environments where the employee is subject to collective bargaining and is a member of a union, while employment law generally deals with individual employment contracts in which the employee is not either a member of a union or bound by a collective bargaining agreement; yet, this difference is too slight that in this research the two terms are exchangeable.

\section{The Sources of European Union Labour Law}

The goal of the European Union as found in the preamble of The Treaty on Functioning of the European Union is "the constant improvements of the living and working conditions of their peoples". EU policies in the labour law filed have sought to achieve high employment $\&$ strong social protection, to improve living $\&$ working conditions, and to protect social cohesion.(European Commission, 2020). It protects the rights of workers across the EU.Generally speaking, the EU labour law covers areas as wide-range as:(1) conditions of employment eg working time, part-time and fixed-term work, posting of workers, discrimination, equal pay and the protection of pregnant workers; (2) informing and consulting workers in collective redundancy and business transfer situations; (3) protection of personal data. The EU labour law framework has a layered structure. According to Fisher et al., in the European Union, laws are divided into the first layer and the second layer legislations. The firs layer consists of the primary laws(treaties), which are the basis or foundation for European Union actions. The second layer legislation is derived from the objectives of the primary 
treaties, and this secondary legislation takes the form of regulations, unilateral acts, directives and decisions.(Fisher, 2016).

Specifically speaking, the first layer, namely, the primary labor laws governing the European Union member states are found in:

\section{The Treaty on Functioning of the European Union in Articles 145-164.}

European Convention on Human Rights articles 4, 6, 9, 10 and 11

\section{European Social Charter 1961}

\section{Community Charter of the Fundamental Social Rights of Workers 1989}

The second layer legislations consist of a group of Directives which create a range of individual rights in EU employment relationships. According to the research by Roger Blanpain, the objective of transnational regulation is to progressively raise the minimum floor in line with economic development.(Blanpain, 2008). Functionally, the laws set forth by the European Union set minimum standards for member states to follow and exceed if those countries so chose. In addition to the guidelines set forth by The Treaty on Functioning of the European Union, additional case law governs topics like equality and employment contracts. Although, as mentioned above, the focus of this research is limited to the diverse aspects as follows: wage issue, collective bargaining, working time issue, migrant worker, health and safety, for the reason that these issues in labour law are usually of high relevance to international investment.(Sassen, 1990). From these aspects, this research will probe into what obstacles the EU labour law will cause to the Chinese investors of infrastructure projects.

\section{Minimum Wage}

Minimum wage issue is highly related to the economic development of a MS in the view of the EU. Therefore, it is primarily left to the Member States to regulate. Meanwhile, at the EU level, there is even an absence of a requirement for the MS to introduce national minimum wages, although there are ongoing calls in the EU Parliament for adopting such requirement in the EU law.(Stupp and Barbière, 2017). Consequently, the situations are varying among the EU states, which is perhaps confusing for Chinese investors.

Regarding whether providing a minimum wage in the national law, different member states have different approaches. According to the Eurofound statistics, 22 out of 28 EU countries apply a generally binding statutory minimum wage. These Member States include Belgium, Bulgaria, Croatia, Czech Republic, Estonia, France, Germany, Greece, Hungary, Ireland, Latvia, Lithuania, Luxembourg, Malta, Netherlands, Poland, Portugal, Romania, Slovakia, Slovenia, Spain and United Kingdom. (European Foundation for the Improvement of Living and Working Conditions, 2017). For instance, the German law provides a statutory minimum wage of EUR 8.84 per hour which generally applies to all employees in all sectors of business.

By comparison, in the majority of EU Member States such as Austria, Denmark, Finland, Italy and Sweden, where there is no statutory minimum wage, the minimum wage level is de facto set in (sectoral) collective agreements. (European Foundation for the Improvement of Living and Working Conditions, 2017). These agreements can become generally binding. For example, in Finland, a public commission under the Ministry of Social Affairs and Health formally decides whether collective agreements are generally binding. Another example is Italy, where while such agreements only apply to enterprises and workers that are members of the bargaining social partners, case law adopts collectively agreed minimum wages as a reference for other employees as well, significantly incentivising their adoption by employers which are not affiliated to signatory employer organisations. In Cyprus, the level of minimum wages is set annually by the government in consultation with the social partners and is enforced by a decree of the Council of Ministers.(European Foundation for the Improvement of Living and Working Conditions, 2017). This means the level of minimum wages can be changing from year to year, at least theoretically speaking. In this regard, it brings about a labour cost uncertainty to infrastructure investors. Nevertheless, a common approach is observed from these states when they regulate the minimum wage issue. That is, social partners are actively involved in negotiating the minimum wage through collective bargaining, which is mostly in the form of the legal instrument Tripartite Councils.( Kohl and Platzer, 2007). Regarding the important role of collective bargaining, or in other words, the involvement of social partners, it will be further discussed later in this research.

\section{Working Time}

Working time is one of the most important areas of employment policy where the EU has intervened through legislation.(Eurofound, 2020). It is also seen as the grey area between traditional health and safety measures and the rights of employed persons. (Barnard, 2012). In the field of working time issue, as compiled by Catherine, the legal instruments include a Council Recommendation of 1975 on the principle of 40-hour week and four weeks' annual paid holiday, and a Resolution of 1979 on the adaptation of working time, the Working Time Directive 93/104/EEC and the 
Young Workers' Directive 94/33/EC.(Barnard, 2012). Compared the former two which focused the reduction in working time, the latter two more on the duration and organization of working time so that an improvement in the living of workers can be improved across the EU.(Barnard, 2012).

The Working Time Directive requires EU Member States to guarantee specific rights regarding working time to all workers, such as minimum periods of rest, annual leave, maximum weekly working time and limits to night and shift work. The working time issue is in nature of relevance to the health and safety issue (see hereafter), because research showed that weekly working time of more than 50 hours could, in the long run, be harmful to health and safety, that working weeks of more than six days showed some correlation with health problems including fatigue and disturbed sleep, and that longer working hours substantially increased the probability of accidents at work ${ }^{1}$.

Among the working time issues, the in-work break requirement shall be paid particular attention to. This requirement is laid down in the Working Time Directive. If the working day is longer than six hours every worker is entitled to an in-work rest break, the details of which, including the duration of the break and the terms on which it is taken must, by preference, be laid down by collective agreement between the two sides of industry or, failing that, by national legislation.(Article 4 of Working Time Directive). This requirement is new to the Chinese investors, because in-work rest break is not mandatory in the Chinese law. The Chinese investors, when investing infrastructure in Europe, shall pay particularly attention to this as the projects usually utilizing large amount of manual workers. Failing to comply with the in-work requirement might lead to not only financial risks, such as fines and sanctions, but also a political risk--- striking. It shall be noted that the social partners are invited to negotiate on this issue. Therefore, the working time is of relevance to the issue of the involvement of the representing bodies.

\section{Migrant Worker}

This is an issue for the Chinese infrastructure investors because the infrastructure projects usually employ Chinese workers brought abroad by construction companies. This is reflected in the fact that the number of Chinese workers abroad has significantly increased in the past decades. These workers are seen as migrant workers. And EU regulates the migrant worker issue at the Union level. and the migrant worker issue is not new to the Union particularly after a massive westward migration after the accession of eastern European countries, due to existing wage differences between eastern and western European countries.(Sinn, 2000). The EU law sees the rights of free movement of persons the cornerstone of the Union. (Barnard, 2012).

According to Barnard's compilation, the EU system also empowers the migrant workers the right to family reunification. The Family Reunification Directive 2003/86 was the first and primary one among the measures put forward by EU Commission. According to it, the right to reunification is dependent on evidence of the existence of accommodation for a comparable family in the same region, sickness insurance for the family members, and stable and regular resources which are higher than or equal to the level of resources which are sufficient to maintain the sponsor and the family members. Furthermore, the Directive allows Member States to require the workers' family members to comply with integration measures, such as attending language courses, in order to ensure the integration of the them.(Barnard, 2012).

Again, according to Barnard's compilation, regarding the long-term residence, the Long Term Residents' Directive 2003/109 is to establish a common status of long-term resident for those migrant workers who have resided legally and continuously for five years in the territory of the MS concerned.(Barnard, 2012). At the same time, a long-term residence permit, valid for at least five years, will be granted where the worker has adequate resources and sickness insurance. It is automatically renewable on expiry. (Barnard, 2012).

In both cases, namely, family reunification and long-term residence, due to the family members' coming to the state concerned and long-term residence of the worker, the labour cost and mobility might be increasing. These have a risk of bringing extra cost to the Chinese infrastructure investors, and therefore are of importance for them to know the system before investing.

\section{Health and Safety}

Health and safety is an important issue of infrastructure construction as a labor-intensive industry, as such being of relevance to the infrastructure investors. In the EU system, it is one of the issues the Union has been concerned since its inception.(Barnard, 2012). Nowadays, the EU has established a comprehensive health and safety law framework built on the Directive 89/391. (Article 5.1) According to it, the employers are generally obliged to ensure health and safety is managed carefully on an infrastructure construction needs. This general duty has been transposed by all Member States respectively in their national laws, though being variously described. As compiled by Catherine who gave the examples of Belgium, Italy and the UK: the duty to ensure " with the diligence of a good father" that work takes place in suitable

\footnotetext{
${ }^{1}$ These evidences are from some studies cited by the European Commission when it considered reducing working time. See: Catherine Barnard. EU Employment Law. OUP Oxford, 2012, p.534
} 
conditions for health and safety and to observe the requirements of law" (Belgium); " to take measures necessary in relation to the type of work and the state of technology to protect the physical and mental welfare for employees' and to observe the requirements of the law" (Italy); and "to ensure so far as reasonably practicable the health, safety, and welfare of all employees" (UK).(Barnard, 2012). Under the general duty, the employers are accorded the obligations, such as risk assessment, health and safety training providing, and combatting the dangers at source. The employee is empowered to stop work in case of imminent dangers. These are all transposed into national laws. (Liu and Liu, 2015). In practicing out the health and safety laws, as a matter of fact, the eastern Europe is generally performing worse than the western member states. For example, in recent years Latvia has ranked either the worst or second-worst performer in terms of workplace fatalities in Europe, at approximately six per 100,000 employees, approximately 50 percent above EU averages. As pointed out by Woolfson, this is exacerbated by weak enforcement and low financial penalties for safety law violations.(Woolfson, 2007)

In addition to physical hazards, the EU system also protect workers against sexual harassment. Article 2(1)(d) of the Equality Treatment Directive defines it as the situation "where any form of unwanted verbal, non-verbal or physical conduct of a sexual nature occurs, with the purpose of violating the dignity of a person, in particular when creating an intimidating, hostile, degrading, humiliating, or offensive environment. As pointed out by Barnard, sexual harassment is a distinct concept covering situation where the behavior is sexual in nature, rather than on the ground of a person's sex. (Barnard, 2012). The Directive requires MS to encourage employers and those responsible for access to vocational training to "take measures to prevent all forms of discrimination on ground of sex, in particular sexual harassment at the workplace".(Article 26 of the Equality Treatment Directive). Also, like observed in other issues, social partners- which are mainly in the form of the workers' representatives - are also empowered to formulating detailed. At the same time, because the infrastructure

\section{Social Partners and Collective Bargaining}

The social partners are the bodies representing the two sides of industry: the employers and the employees. They are essential participators in rule-formulating in many sectors in the EU system.(Atkinson, 2009). Collective bargaining is a fundamental principle of the EU labour law. The fundamental principle of labour law is that employees' unequal bargaining power justifies substitution of rules in property and contract with positive social rights so that people may earn a living to fully participate in a democratic society. In practice, the Union has focused particular attention on encouraging dialogue between workers/their representatives and their employers.(Barnard, 2012). In this regard, the European trade unions have a key role in implementing a policy in the following sectors concerned in this research: European minimum wage, working time, and health and safety (see the above sections: 3 to 7). As concluded by Schulten et al., they can develop their own concept in the above sectors.(Schulten, 2018). At the same time, as pointed out by Barnard, participation can be regarded as a generic term embracing all types of industrial democracy, ranging from information, consultation, and collective bargaining, to more extensive involvement in the employers' decision making.(Barnard, 2012). Barnard's classification of worker's involvement is helpful to studying the roles of industrial democracy in legal studies, because it provides an exhausted list of different types of workers' participation at the industrial level.

As repeatedly pointed out before, the infrastructure construction is per se an labour-intensive activity. Consequently, the social partners participation is in nature a new phenomenon to Chinese investors in infrastructure. The impact of the participation shall be of concern to the investors. For example, resources that are devoted to the participation shall be considered when the investors make the investment plans. But, all the detailed impacts will be further discussed in the following discussion section.

\section{Discussion}

It is argued that the EU has established a comprehensive labour law framework. Based on the above observations, the EU labour law system might present legal obstacles to the Chinese infrastructure investors from several aspects as follows:

Firstly, as noted in section 3, the minimum wage issue is not regulated at the European Union level. Instead, it is left to Member States. Some Member states regulate this issue primarily on collective agreements. As such, it is not possible to formulate a unified legal strategy to deal with wage issue arising from China's infrastructure investment across the European Union. Instead, the effective solution might be that the investors shall study beforehand what the approach is taken in the legal system of the targeted member state that they are going to invest in. That is to say, to make different investment policies regarding minimum wage towards different Member States. This approach seems to best suit the current situation

Secondly, under the working-time issue, the EU law has provide an in-work break requirement. As demonstrated before in section 4, this requirement is a new phenomenon to the Chinese investors. Violation of the requirement might lead to 
administrative sanctions from the labour inspections, from the legal perspective; and striking, from the industrial relation perspective. As such, the Chinese infrastructure investors shall choose contractors which are competent to carry out the obligation to providing workers in-work break, or outside services. When the investors make investment plans, they shall have apart budget for providing in-work break facilities such as break rooms, coffee, comfortable seating.

Thirdly, migrant worker issue has the legal impact on the infrastructure investor. As a usual practice, the infrastructure companies bring almost all the workers from China. These workers, as analyzed in section 5, are entitled to apply for family reunification and long-term resident permit after some certain years of working, if meeting the legal requirements. This needs not only the infrastructure investors be acknowledged of the workers' entitlements in this field, but also provide relating resources to assist the workers to exercise their rights. However, as a matter of fact, this will increase the cost born by the investors: on the one hand, providing resources and assistance cost money; on the other hand, particularly in case where the workers have obtained long-term resident permit, they are then free to work elsewhere, not limited to the infrastructure construction anymore. In this case, they may swift to occupation with better payment. And the infrastructure construction has to recruit new workers instead. This also increase their costs.

Fourthly, the issue concerning involved of workers representing bodies. Free collective bargaining is highly valued in Europe. The EU law system contains juridical clauses concerning how collective bargaining has to be put into practice and how it is intended to work. The involvement of worker representing bodies is also relevant to other legal issues examined in this research, as they are also empowered to negotiate on health and safety issues, work time issues, health and safety, etc. This is an obstacle to Chinese fundamental infrastructure investors, partly because, the Chinese legal system has not established such an institution in its law system; and partly because the free collective bargaining has been exposed to continuous assaults by conservative and liberal forces due to the fears of making the Chines industries uncompetitive.

A possible solution might be that Chinese companies should therefore consider implementing their own policies that afford employees collective bargaining power. At the same time, it is also noted that an open internal channel with worker representatives would go a long way to both ensuring employee satisfaction and preventing disruption. In this regard, Chinese companies shall try to understand the European labour right to engage in collective bargaining in both law and practice.

\section{Final Remarks}

All of the above issues are presenting potential legal obstacles arising from the labour law which the Chinese infrastructure investors might face when they invest in the European Union. As former statesman and reformist Xiaoping Deng said "move steadily and look before you leap", a better solution might be as simply as "best try while best learn".

\section{Acknowledgement:}

this research is supported by:

1. Jiangsu Research Funding of Philosophy and Social Sciences, 2018SJA0922

2. Jiangsu Shuangchuang Research Program (Shuangchuang PhDs), Year 2018

3. Jiangsu Normal University Teachers' Research Funding 18XWRS011

4. Jiangsu Normal University Booking Publishing Funding JYJC202003

\section{References}

A. T. J. M. Jacobs. Labour Law in the Netherlands. Kluwer Law International, 2004.

Alan Neal. European Labour Law and Policy:Cases and Materials. Kluwer Law International, 2002

Anne van, A. (2009). International Investment Law Between Commitment and Flexibility: A Contract Theory Analysis. Journal of International Economic Law, 12(2), 507-538. https://doi.org/10.1093/jiel/jgp022

Atkinson, A. (2009). The EU and social inclusion: facing the challenges (2nd). Policy Press.

Barnard, C. (2012). EU Employment Law. OUP Oxford

Bartlomiej, K. (2020). How Accession to the European Union Has Affected External Trade and Foreign Direct Investment in Central European Economies. World Bank Policy Research Working Paper No. 2578. Retrieved June 15, 2020, from http://citeseerx.ist.psu.edu/viewdoc/download?doi=10.1.1.17.8848\&rep=rep1\&type=pdf

Blanpain, R. (2008). European Labour Law. Kluwer Law International.

Brian, B. (2009). European Labour Law. Cambridge University Press, 2009.

Casaburi, I. Chinese investment trends in Europe 2016-17 report. (2018). China Europe Club. Retrieved from: http://itemsweb.esade.edu/research/esadegeo/ChineseInvestmentTrendsInEurope.pdf

Charles, N. B., \& Stephan, W. S. (2008). Is Arbitration a Threat or a Boom to the Legitimacy of International Investment Law. Chicargo Journal of International Law, 9(2), 471-498. 
Clegg, J., \& Voss, H. (2020, April 12). Chinese overseas direct investment in the European Union. Europe China Research and Advice Network. Retrieved from https://www.eu-china.net/upload/pdf/materialien/12-08_ECRAN_Chinese_direct_investment_in_the_EU.pdf

David, M. T., \& Louise, G. T. (2005). Hard and Soft Law in the Construction of Social Europe: The Role of the Open Method of Co-ordination. European Law Journal, 11(3), 343-364. https://doi.org/10.1111/j.1468-0386.2005.00263.x

Eurofound. (2020). Working Time and Work-Life Balance. Retrieved from https://www.eurofound.europa.eu/observatories/eurwork/about-eurwork/working-time-and-work-life-balance

European Commission. (2020). Employment, Social Affairs and Inclusion. Retrieved from http://ec.europa.eu/social/main.jsp?catId=157

European Foundation for the Improvement of Living and Working Conditions. (2017). Statutory minimum wages in the EU 2016. Retrieved from https://www.eurofound.europa.eu/observatories/eurwork/articles/working-conditions-industrial-relations/statutoryminimum-wages-in-the-eu-2016

Fisher, C., Putman, C., \& Hassani, A. (2016). European Union labor law: a comparison between the labor laws of the United States and the European Union. The Business and Management Review, 7(5), 43-50.

Françoise, N. (2014). China's direct investment in the European Union: challenges and policy responses. China Economic Journal, 7(1), 103-125. https://doi.org/10.1080/17538963.2013.874070

Helen, W., Mark, A. P., \& Alasdair, R. Y. (2014). Policy-making in the European Union. Oxford University Press, 2015.

James, S. M., \& David, M. T. (2003). Alternative Approaches to Governance in the EU: EU Social Policy and the European Employment Strategy. Journal of Common Market Studies, 41(1), 63-88. https://doi.org/10.1111/1468-5965.00411

Jan, P., \& Martin, Š. (2010). Labour Law in Czech Republic. Kluwer Law International, 2010.

Janice, N. (2013). Employment Law Statutes 2011-2012. Routledge, 2013.

Jeremy, C., \& Hinrich, V. (2020). Chinese Overseas Direct Investment in The European Union. Retrieved June 15, 2020, from https://www.eu-china.net/upload/pdf/materialien/12-08_ECRAN_Chinese_direct_investment_in_the_EU.pdf

Jim, B. (2004). Comparative Labour Law and Industrial Relations in Industrialized Market Economies. Kluwer Law International, 2004.

Julian, D. M. (2010). The Meaning of 'Investment': ICSID's Travaux and the Domain of International Investment Law. Harvard International Law Journal, 51(1), 257-318.

Ke, C. (2011). Labour Law in China. Kluwer Law International, 2011.

Kimberly, A. C., \& Cosmina, L. D. (2005). Re-entering Europe: Does European Union Candidacy Boost Foreign Direct Investment? Economics of Transition, 13(1), 77-103. https://doi.org/10.1111/j.1468-0351.2005.00208.x

Kohl, H., \& Platzer, H. (2007). The role of the state in central and eastern European industrial relations: the case of minimum wages. Industrial Relations Journal, 38(6), 614-635. https://doi.org/10.1111/j.1468-2338.2007.00466.x

Lars, O., \& Pervez, N. G. (2004). European Union and the Race for Foreign Direct Investment in Europe. Emerald Group Publishing, 2004.

Liu, K., \& Liu, W. (2015). The development of EU law in the field of occupational health and safety: a new way of thinking. Management and Labour Studies, 40(3), 1-32. https://doi.org/10.1177/0258042X15624990

McKenzie, B. (October 11, 2017). Chinese investment tripled in US in 2016, doubled in Europe. China Business Review. Retrieved from https://www.chinabusinessreview.com/chinese-investment-tripled-in-us-in-2016-doubled-in-europe/

Mitchell, T., Chazan, G., \& Weinland, D. (2020, April 11). Chinese investment in EU dwarfs flow the other way. Financial Times. Retrieved from https://www.ft.com/content/79e3a2b2-d6f7-11e6-944b-e7eb37a6aa8e

Ole, H. (2010). Labour Law in Denmark. Kluwer Law International, 2010.

Peter, M., Federico, O., \& Christoph, S. (2008). The Oxford Handbook of International Investment Law. Oxford University Press, 2008.

Roger, B. (2008). European Labour Law. Kluwer Law International, 2008.

Roger, B. (2010). Labour Law in Belgium. Kluwer Law International, 2010.

Saskia, S. (1990). The Mobility of Labor and Capital: A Study in International Investment and Labor Flow. Cambridge University Press, 1990.

Schulten, T., Rieger, A., Ringger, B., Baumann, H., Husson, M., \& Math. A. (2018). Theses for a European minimum wage policy. CLR-NEWS. Retrieved from http://clr-news.org/CLR-News/CLR\%20News\%203-2005.pdf\#page=54

Sinn, H. (2000). EU enlargement and the future of the welfare state. CESifo Working Paper. Retrieved from https://www.econstor.eu/bitstream/10419/75552/1/cesifo_wp307.pdf 
Sophie, M. (2014). 'Beggars can't be Choosers': The European Crisis and Chinese Direct Investment in the European Union. Journal of European Integration, 36(3), 283-302. https://doi.org/10.1080/07036337.2014.885754

Stephan, W. S. (2009). The Multilateralization of International Investment Law. Cambridge University Press, 2009

Stephen, T. H., \& Stephen, H. (2011). Labour Law in Great Britain. Kluwer Law International, 2011.

Stupp, C., \& Barbière, C. (2017, January 20). MEPs call for EU law requiring minimum wage in every country. EURACTIV. Retrieved from

https://www.euractiv.com/section/social-europe-jobs/news/meps-call-for-eu-law-requiring-national-minimum-wag e-in-every-country/

Woolfson, C. (2007). Labour Standards and Migration in the New Europe: Post-Communist Legacies and Perspectives. https://doi.org/10.1177/0959680107078253

\section{Copyrights}

Copyright for this article is retained by the author(s), with first publication rights granted to the journal.

This is an open-access article distributed under the terms and conditions of the Creative Commons Attribution license which permits unrestricted use, distribution, and reproduction in any medium, provided the original work is properly cited. 